\title{
Front Matter: Volume 8982
}

, "Front Matter: Volume 8982," Proc. SPIE 8982, Optical Components and Materials XI, 898201 (25 March 2014); doi: 10.1117/12.2063493

SPIE. Event: SPIE OPTO, 2014, San Francisco, California, United States 


\section{PROCEEDINGS OF SPIE}

\section{Optical Components and Materials XI}

Michel J. F. Digonnet

Shibin Jiang

Editors

3-5 February 2014

San Francisco, California, United States

Sponsored and Published by

SPIE 
The papers included in this volume were part of the technical conference cited on the cover and title page. Papers were selected and subject to review by the editors and conference program committee. Some conference presentations may not be available for publication. The papers published in these proceedings reflect the work and thoughts of the authors and are published herein as submitted. The publisher is not responsible for the validity of the information or for any outcomes resulting from reliance thereon.

Please use the following format to cite material from this book:

Author(s), "Title of Paper," in Optical Components and Materials XI, edited by Michel J. F. Digonnet, Shibin Jiang, Proceedings of SPIE Vol. 8982 (SPIE, Bellingham, WA, 2014) Article CID Number.

ISSN: 0277-786X

ISBN: 9780819498953

Published by

SPIE

P.O. Box 10, Bellingham, Washington 98227-0010 USA

Telephone +1 3606763290 (Pacific Time) · Fax +1 3606471445

SPIE.org

Copyright (C) 2014, Society of Photo-Optical Instrumentation Engineers.

Copying of material in this book for internal or personal use, or for the internal or personal use of specific clients, beyond the fair use provisions granted by the U.S. Copyright Law is authorized by SPIE subject to payment of copying fees. The Transactional Reporting Service base fee for this volume is $\$ 18.00$ per article (or portion thereof), which should be paid directly to the Copyright Clearance Center (CCC), 222 Rosewood Drive, Danvers, MA 01923. Payment may also be made electronically through CCC Online at copyright.com. Other copying for republication, resale, advertising or promotion, or any form of systematic or multiple reproduction of any material in this book is prohibited except with permission in writing from the publisher. The CCC fee code is 0277-786X/14/\$18.00.

Printed in the United States of America.

Publication of record for individual papers is online in the SPIE Digital Library.

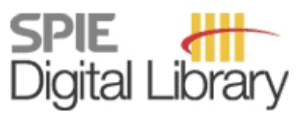

SPIEDigitalLibrary.org

Paper Numbering: Proceedings of SPIE follow an e-First publication model, with papers published first online and then in print and on CD-ROM. Papers are published as they are submitted and meet publication criteria. A unique, consistent, permanent citation identifier (CID) number is assigned to each article at the time of the first publication. Utilization of CIDs allows articles to be fully citable as soon as they are published online, and connects the same identifier to all online, print, and electronic versions of the publication. SPIE uses a six-digit CID article numbering system in which:

- The first four digits correspond to the SPIE volume number.

- The last two digits indicate publication order within the volume using a Base 36 numbering

system employing both numerals and letters. These two-number sets start with 00, 01, 02, 03, 04, $05,06,07,08,09,0 A, 0 B \ldots 0 Z$, followed by 10-1Z, 20-2Z, etc.

The CID Number appears on each page of the manuscript. The complete citation is used on the first page, and an abbreviated version on subsequent pages. Numbers in the index correspond to the last two digits of the six-digit CID Number. 


\section{Contents}

xiii Conference Committee

\section{SESSION $1 \quad$ LASERS AND AMPLIFIERS}

898202 High power resonantly pumped holmium-doped fibre sources (Invited Paper) [8982-1] A. Hemming, N. Simakov, J. Haub, Defence Science and Technology Organisation (Australia); A. Carter, Nufern (United States)

898203 Titanium enhanced Raman microcavity laser [8982-2]

N. Deka, A. J. Maker, A. M. Armani, The Univ. of Southern California (United States)

898204 Fibercore AstroGain fiber: multichannel erbium doped fibers for optical space communications [8982-3]

M. Hill, R. Gray, J. Hankey, A. Gillooly, Fibercore Ltd. (United Kingdom)

898206 Spatially resolved in-core temperature measurement in rare-earth doped fibers during pumping [8982-5]

J. Fiebrandt, M. Leich, S. Unger, A. Schwuchow, M. Jäger, M. Rothhardt, H. Bartelt, Institut für Photonische Technologien e.V. (Germany)

898207 Low-threshold integrated microlaser emitting in the blue formed from thulium doped silica [8982-6]

S. Mehrabani, A. M. Armani, The Univ. of Southern California (United States)

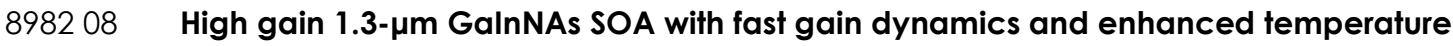
stability [8982-7]

D. Fitsios, Ctr. for Research and Technology Hellas (Greece) and Aristotle Univ. of Thessaloniki (Greece); G. Giannoulis, N. lliadis, National Technical Univ. of Athens (Greece); V.-M. Korpijärvi, J. Viheriälä, A. Laakso, Tampere Univ. of Technology (Finland); S. Dris, M. Spyropoulou, H. Avramopoulos, National Technical Univ. of Athens (Greece); G. T. Kanellos, Ctr. for Research and Technology Hellas (Greece); N. Pleros, Ctr. for Research and Technology Hellas (Greece) and Aristotle Univ. of Thessaloniki (Greece); M. Guina, Tampere Univ. of Technology (Finland)

\section{SESSION 2 NANOPHOTONICS}

8982 0A Investigation of liquid crystal materials doped with quantum dots: properties and potential applications [8982-9]

K. Komorowska, K. Zygadlo, B. Cichy, M. Nikodem, Wroclaw Research Centre ElT+ (Poland) 
8982 OC Materials growth and processing in the capillaries of photonic crystal fibres: towards the lab-in-a-fibre protocol (Invited Paper) [8982-11]

I. Konidakis, M. Konstantaki, S. Pissadakis, Foundation for Research and Technology-Hellas (Greece)

8982 OD $\quad \mathrm{GeO}_{2}$ glass ceramic planar waveguides fabricated by RF-sputtering [8982-12]

A. Chiasera, CSMFO Lab., CNR-IFN, Univ. degli Studi di Trento (Italy); C. Macchi, IFIMAT, CONICET, Univ. Nacional del Centro de la Provincia de Buenos Aires (Argentina);

S. Mariazzi, INFN, Univ. degli Studi di Trento (Italy); S. Valligatla, CSMFO Lab., CNR-IFN, Univ. degli Studi di Trento (Italy) and Univ. of Hyderabad (India); S. Varas, M. Mazzola, CSMFO Lab., CNR-IFN, Univ. degli Studi di Trento (Italy); N. Bazzanella, Univ. degli Studi di Trento (Italy); L. Lunelli, C. Pederzolli, Fondazione Bruno Kessler (Italy); D. N. Rao, Univ. of Hyderabad (India); G. C. Righini, Museo Storico della Fisica e Centro Studi e Ricerche Enrico Fermi (Italy); A. Somoza, IFIMAT, CICPBA, Univ. Nacional del Centro de la Provincia de Buenos Aires (Argentina); R. S. Brusa, CNISM, Univ. degli Studi di Trento (Italy); M. Ferrari, CSMFO Lab., CNR-IFN, Univ. degli Studi di Trento (Italy)

8982 OE Low-loss titanium-dioxide strip waveguides by atomic layer deposition [8982-13] M. Roussey, M. Häyrinen, Univ. of Eastern Finland (Finland); A. Säynätjoki, Aalto Univ. (Finland); V. Gandhi, Univ. of Eastern Finland (Finland); L. Karvonen, Aalto Univ. (Finland); P. Stenberg, M. Kuittinen, S. Honkanen, Univ. of Eastern Finland (Finland)

8982 OF Drawing robust infrared optical fibers from preforms produced by efficient multimaterial stacked coextrusion [8982-14]

G. Tao, A. F. Abouraddy, CREOL, The College of Optics and Photonics, Univ. of Central Florida (United States)

8982 OG Flexible glass flat-fibre chips and femtosecond laser inscription as enabling technologies for photonic devices [8982-15]

C. Riziotis, National Hellenic Research Foundation (Greece); K. Kalli, Cyprus Univ. of Technology (Cyprus); C. Markos, National Hellenic Research Foundation (Greece);

A. Posporis, C. Koutsides, Cyprus Univ. of Technology (Cyprus); A. S. Webb, C. Holmes, J. C. Gates, J. K. Sahu, P. G. R. Smith, Univ. of Southampton (United Kingdom)

8982 Ol Ultrathin metals and nano-structuring for photonic applications (Invited Paper) [8982-17] N. Formica, A. Carrilero, T. L. Chen, D. S. Ghosh, Institut de Ciències Fotòniques (Spain); P. Mazumder, Corning Incorporated (United States); V. Pruneri, Institut de Ciències Fotòniques (Spain) and Institució Catalana de Recerca i Estudis Avançats (Spain)

8982 0J Metamaterial selective emitters for photodiodes [8982-18]

D. F. DeMeo, N. A. Pfeister, C. M. Shemelya, Tufts Univ. (United States) T. Vandervelde, Tufts Univ. (United States) and The Univ. of Texas at El Paso (United States)

8982 OK Multilevel light bending in nanoplasmonics [8982-19]

M. H. El Sherif, O. S. Ahmed, M. H. Bakr, McMaster Univ. (Canada); M. A. Swillam, The American Univ. in Cairo (Egypt) 
$8982 \mathrm{OL} \quad H u y g e n s$ lens for angle compensation [8982-20]

Q. Lévesque, ONERA (France) and Lab. de Photonique et de Nanostructures, CNRS

(France); P. Bouchon, ONERA (France); F. Pardo, J.-L. Pelouard, Lab. de Photonique et de Nanostructures, CNRS (France); R. Haïdar, ONERA (France) and École Polytechnique (France)

8982 OM Toward dynamic metamaterials for monothically integrated multilayer polarization filters [8982-21]

N. Pfiester, Tufts Univ. (United States); C. Shemelya, The Univ. of Texas at El Paso (United States); T. Rotter, G. Balakrishnan, The Univ. of New Mexico (United States);

T. E. Vandervelde, Tufts Univ. (United States)

\section{SESSION 5 MICROSTRUCTURED FIBERS AND COMPONENTS}

$8982 \mathrm{ON}$ Unusual 3D lithography approaches for fabrication of polymeric photonic microstructures (Invited Paper) [8982-22]

S. Coppola, V. Vespini, F. Merola, B. Mandracchia, S. Grilli, P. Ferraro, Istituto Nazionale di Ottica del CNR (Italy)

898200 Nanolaminate structures fabricated by ALD for reducing propagation losses and enhancing the third-order optical nonlinearities [8982-23]

L. Karvonen, T. Alasaarela, H. Jussila, Aalto Univ. (Finland); S. Mehravar, College of Optical Sciences, The Univ. of Arizona (United States); Y. Chen, A. Säynätjoki, Aalto Univ. (Finland); R. A. Norwood, N. Peyghambarian, K. Kieu, College of Optical Sciences, The Univ. of Arizona (United States); S. Honkanen, Univ. of Eastern Finland (Finland); H. Lipsanen, Aalto Univ. (Finland)

8982 OP Split gate and asymmetric contact carbon nanotube optical devices [8982-24] M. A. Hughes, K. P. Homewood, R. J. Curry, Univ. of Surrey (United Kingdom); Y. Ohno, T. Mizutani, Nagoya Univ. (Japan)

\section{SESSION $6 \quad$ YB-DOPED GLASSES AND FIBERS}

8982 OR Optical properties of Yb-doped fibers prepared by gas phase doping [8982-27] F. Lindner, C. Aichele, A. Schwuchwo, M. Leich, A. Scheffel, S. Unger, Institut für Photonische Technologien e.V. (Germany)

8982 OS Gamma-radiation-induced degradation of actively pumped single-mode ytterbiumdoped optical fibers [8982-28]

B. Singleton, J. Petrosky, M. Pochet, Air Force Institute of Technology (United States); N. G. Usechak, Air Force Research Lab. (United States); S. A. Francis, Air Force Institute of Technology (United States)

8982 OT Impact of photodarkening on $\mathrm{Yb}$ lifetime in Al-silicate fibres and on the rate-equation system [8982-29]

R. Piccoli, Swansea Univ. (United Kingdom); T. Robin, iXFiber S.A.S. (France); D. Méchin, PERFOS (France); S. Taccheo, Swansea Univ. (United Kingdom) 
$8982 \mathrm{OV}$ Up-conversion emission tuning in triply-doped $\mathrm{Yb}^{3+} / \mathrm{Tm}^{3+} / \mathrm{Er}^{3+}$ novel fluoro-phosphate glass and glass-ceramics [8982-31]

Y. Ledemi, A.-A. Trudel, Univ. Laval (Canada); V. A. G. Rivera, Univ. de São Paulo (Brazil);

Y. Messaddeq, Univ. Laval (Canada)

SESSION 7 COMPONENTS AND DETECTORS

8982 OW Reliability considerations of high speed germanium waveguide photodetectors (Invited Paper) [8982-32]

Z. Tu, Z. Zhou, X. Wang, Peking Univ. (China)

8982 OY Fast and precise continuous focusing with focus tunable lenses [8982-34]

S. Casutt, M. Bueeler, M. Blum, M. Aschwanden, Optotune AG (Switzerland)

898210 High spectral contrast filtering produced by multiple pass reflections from paired Bragg gratings in PTR glass [8982-36]

D. Ott, M. SeGall, I. Divliansky, G. Venus, L. Glebov, CREOL, The College of Optics and Photonics, Univ. of Central Florida (United States)

898211 Design and characterization of avalanche photodiodes in submicron CMOS technologies [8982-37]

L. Pancheri, Univ. degli Studi di Trento (Italy); T. Bendib, Univ. degli Studi di Trento (Italy) and Univ. of Batna (Algeria); G.-F. Dalla Betta, Univ. degli Studi di Trento (Italy); D. Stoppa,

Fondazione Bruno Kessler (Italy)

\section{SESSION 8 OPTICAL AND ELECTRONIC PROPERTIES OF MATERIALS}

898212 Plasmonic enhancement of lanthanides luminescence using metallic nanoparticles (Invited Paper) [8982-26]

A. Berthelot, Institut Lumière Matière, CNRS, Univ. de Lyon 1 (France); S. Derom, Lab. Interdisciplinaire Carnot de Bourgogne, CNRS, Univ. de Bourgogne (France); N. Abdellaoui, O. Benamara, A. Pillonnet, A. Pereira, Institut Lumière Matière, CNRS, Univ. de Lyon 1 (France); G. Colas des Francs, Lab. Interdisciplinaire Carnot de Bourgogne, CNRS, Univ. de Bourgogne (France); B. Moine, A.-M. Jurdyc, Institut Lumière Matière, CNRS, Univ. de Lyon 1 (France)

898213 Electrical properties of amorphous chalcogenide/silicon heterojunctions modified by ion implantation [8982-38]

Y. G. Fedorenko, M. A. Hughes, J. L. Colaux, C. Jeynes, R. M. Gwilliam, K. P. Homewood, Univ. of Surrey (United Kingdom); J. Yao, D. W. Hewak, Univ. of Southampton (United Kingdom); T.-H. Lee, S. R. Elliott, Univ. of Cambridge (United Kingdom); B. Gholipour, Nanyang Technological Univ. (Singapore); R. J. Curry, Univ. of Surrey (United Kingdom)

$898214 \quad$ Multi-band reflectance spectroscopy of carbonaceous lithium iron phosphate battery electrodes versus state of charge [8982-39]

R. Norris, K. Iyer, V. Chabot, P. Nieva, A. Yu, A. Khajepour, Univ. of Waterloo (Canada); J. Wang, General Motors of Canada Ltd. (Canada) 
898215 Persistent luminescence in $\mathrm{ZnGa}_{2} \mathrm{O}_{4}: \mathrm{Cr}$ : an outstanding biomarker for in-vivo imaging [8982-40]

S. K. Sharma, A. Bessiere, D. Gourier, L. Binet, B. Viana, Institut de Recherche de Chimie Paris, CNRS (France); N. Basavaraju, K. R. Priolkar, Goa Univ. (India); T. Maldiney,

D. Scherman, C. Richard, INSERM, Unité de Technologies Chimiques et Biologiques pour la Santé, CNRS, Univ. Paris Descartes (France)

898216 Optical and electronic properties of bismuth-implanted glasses [8982-41]

M. A. Hughes, Y. Federenko, Univ. of Surrey (United Kingdom); T. H. Lee, Univ. of Cambridge (United Kingdom); J. Yao, B. Gholipour, Univ. of Southampton (United Kingdom);

R. M. Gwilliam, K. P. Homewood, Univ. of Surrey (United Kingdom); D. W. Hewak, Univ. of Southampton (United Kingdom); S. R. Elliott, Univ. of Cambridge (United Kingdom);

R. J. Curry, Univ. of Surrey (United Kingdom)

898217 Quantitative characterization of photodoping phenomena in amorphous chalcogenide GeS2 film [8982-42]

Y. Murakami, Tokai Univ. (Japan) and Tsukuba Univ. of Technology (Japan); M. Wakaki,

Tokai Univ. (Japan)

\section{SESSION 9 SENSORS}

898219 Longitudinal strain sensing with photonic crystal fibers and fiber Bragg gratings [8982-44] T. Tenderenda, M. Murawski, M. Szymanski, Military Univ. of Technology (Poland) and InPhoTech Ltd. (Poland); L. Szostkiewicz, InPhoTech Ltd. (Poland); M. Becker, M. Rothhardt, H. Bartelt, Institut für Photonische Technologien e.V. (Germany); P. Mergo, K. Poturaj, M. Makara, K. Skorupski, Univ. Marii Curie-Sklodowskiej (Poland); P. Marc, L. R. Jaroszewicz, Military Univ. of Technology (Poland); T. Nasilowski, Military Univ. of Technology (Poland) and InPhoTech Ltd. (Poland)

$89821 \mathrm{~A} \quad$ Super low power consumption middle infrared LED-PD optopairs for chemical sensing [8982-46]

N. D. Stoyanov, K. M. Salikhov, K. V. Kalinina, S. S. Kizhaev, A. V. Chernyaev, LED Microsensor NT, LLC (Russian Federation)

8982 1B Influence of the mode field diameter on the strain sensitivity of different fibers [8982-47] M. Murawski, T. Tenderenda, M. Napierała, Military Univ. of Technology (Poland) and InPhoTech Ltd. (Poland); L. Szostkiewicz, InPhoTech Ltd. (Poland); A. Lukowski, Z. Hołdyński, M. Szymański, Military Univ. of Technology (Poland) and InPhoTech Ltd. (Poland);

M. Słowikowski, InPhoTech Ltd. (Poland); L. Ostrowski, Military Univ. of Technology (Poland) and InPhoTech Ltd. (Poland); P. Marc, L. R. Jaroszewicz, Military Univ. of Technology (Poland); T. Nasiłowski, Military Univ. of Technology (Poland) and InPhoTech Ltd. (Poland) 
8982 1C Evanescent field scanning optical microscopy [8982-48]

V. Sukharenko, R. Dorsinville, The City College of New York (United States)

8982 1D Diode pumped white light emission from dysprosium and samarium doped glasses [8982-49]

B. R. Reddy, V. M. Edwards, R. Surabhi, Alabama A\&M Univ. (United States)

$8982 \mathrm{lE}$ Continuously tunable dual-wavelength fiber laser using two polymer Bragg grating filters [8982-50]

B. K. Choi, Y. S. Kwon, I. G. Park, Chungnam National Univ. (Korea, Republic of); J. G. Seo, H. K. Lee, ChemOptics Inc. (Korea, Republic of); M. Y. Jeon, Chungnam National Univ. (Korea, Republic of)

$8982 \mathrm{lF} \quad$ Optical glass with tightest refractive index and dispersion tolerances for high-end optical designs [8982-51]

R. Jedamzik, S. Reichel, P. Hartmann, SCHOTT AG (Germany)

8982 1G Characterization of diced ridge waveguides in pure and Er-doped lithium-niobate-oninsulator (LNOI) substrates [8982-52]

C. E. Rüter, S. Suntsov, D. Kip, Helmut-Schmidt Univ. (Germany); G. Stone, V. Dierolf, Lehigh Univ. (United States); H. Hu, W. Sohler, Univ. Paderborn (Germany)

$89821 \mathrm{H} \quad$ Acousto-optical tunable transmissive grating beam splitter [8982-53]

A. Dieulangard, Univ. Lille Nord de France (France), Univ. de Valenciennes et du HainautCambrésis, CNRS (France) and AA Opto-Electronic Co. (France); J.-C. Kastelik, S. Dupont, J. Gazalet, Univ. Lille Nord de France (France) and Univ. de Valenciennes et du HainautCambrésis, CNRS (France)

$89821 \mathrm{~J}$ Superluminal propagation in a highly nonlinear fiber embedded in a Brillouin laser ring cavity [8982-55]

D. Deng, W. Gao, M. Liao, Z. Duan, T. Cheng, T. Suzuki, Y. Ohishi, Toyota Technological Institute (Japan)

$89821 \mathrm{~K}$ Experimental and theoretical study of supercontinuum generation in an $\mathrm{As}_{2} \mathrm{~S}_{3}$ chalcogenide microstructured optical fiber [8982-56]

W. Gao, Toyota Technological Institute (Japan) and Hefei Univ. of Technology (China): M. El Amraoui, Univ. Laval (Canada); M. Liao, H. Kawashima, Z. Duan, D. Deng, T. Cheng, T. Suzuki, Toyota Technological Institute (Japan); Y. Messaddeq, Univ. Laval (Canada); Y. Ohishi, Toyota Technological Institute (Japan)

8982 IL Broadband optical parametric gain by novel highly nonlinear tellurite hybrid microstructured optical fiber with four zero-dispersion wavelengths [8982-57] T. H. Tuan, T. Cheng, K. Asano, Z. Duan, T. Suzuki, Y. Ohishi, Toyota Technological Institute (Japan) 
$89821 \mathrm{M}$ In-band pumping of Tm doped single mode tellurite composite fiber [8982-58] K. Li, Shanghai Institute of Optics and Fine Mechanics (China); X. Fan, Shanghai Institute of Optics and Fine Mechanics (China) and Univ. of Chinese Academy of Sciences (China); L. Zhang, C. Yu, Shanghai Institute of Optics and Fine Mechanics (China); W. Li, P. Kuan, Shanghai Institute of Optics and Fine Mechanics (China) and Univ. of Chinese Academy of Sciences (China); D. Chen, L. Hu, Shanghai Institute of Optics and Fine Mechanics (China)

898210 Study of bi-alkali photocathode growth on glass by $\mathbf{x}$-ray techniques for fast timing response photomultipliers [8982-61]

J. Xie, M. Demarteau, R. Wagner, Argonne National Lab. (United States); M. Ruiz-Oses, X. Liang, I. Ben-Zvi, Stony Brook Univ. (United States); K. Attenkofer, Brookhaven National Lab. (United States); S. Schubert, Brookhaven National Lab. (United States) and HelmholtzZentrum (Germany); J. Smedley, Brookhaven National Lab. (United States); J. Wong, H. Padmore, Lawrence Berkeley National Lab. (United States); A. Woll, Cornell Univ. (United States)

8982 IP A highly-nonlinear three-core chalcogenide-tellurite fiber [8982-62] T. Cheng, N. Asyikin, W. Gao, M. Liao, D. Deng, Toyota Technological Institute (Japan); M. Matsumoto, T. Misumi, Furukawa Denshi Co., Ltd. (Japan); T. Suzuki, Y. Ohishi, Toyota Technological Institute (Japan)

8982 IR Optical RAM row access using WDM-enabled all-passive row/column decoders [8982-64] S. Papaioannou, T. Alexoudi, Ctr. for Research and Technology Hellas (Greece) and Aristotle Univ. of Thessaloniki (Greece); G. T. Kanellos, Ctr. for Research and Technology Hellas (Greece); A. Miliou, N. Pleros, Ctr. for Research and Technology Hellas (Greece) and Aristotle Univ. of Thessaloniki (Greece)

8982 is Infrared absorption and fluorescence properties of $\mathrm{Ho}$-doped $\mathrm{KPb}_{2} \mathrm{Br}_{5}$ [8982-66] E. E. Brown, U. Hömmerich, S. Hyater-Adams, Hampton Univ. (United States); O. Oyebola, Univ. of Lagos (Nigeria); A. Bluiett, Elizabeth City State Univ. (United States); S. B. Trivedi, Brimrose Corp. of America (United States)

8982 1T A novel acousto-optic modulation-deflection mechanism using refractive index grating as graded index beam router [8982-67]

A. Jangjoo, M. Reza Baezzat, A. Razavizadeh, Payam Noor Univ. of Shiraz (Iran, Islamic Republic of)

$89821 \mathrm{U}$ Development of chalcogenide glass with thermal stability for molded infrared lens [8982-68]

J. H. Choi, D. H. Cha, H. Y. Kang, J.-H. Kim, H.-J. Kim, Korea Photonics Technology Institute (Korea, Republic of)

$89821 \mathrm{~V}$ Broadband photosensor with a tunable frequency range, built on the basis of nanoscale carbon structure with field localization [8982-69]

A. N. Yakunin, Institute of Precision Mechanics and Control (Russian Federation); G. G. Akchurin, Institute of Precision Mechanics and Control (Russian Federation) and N.G. Chernyshevsky Saratov State Univ. (Russian Federation); N. P. Aban'shin, B. I. Gorfinkel, Volga-Svet Co. Ltd. (Russian Federation)

$89821 \mathrm{~W}$ Light-induced self-written waveguides based on NaYF/polymer composites for the Cband amplification [8982-70]

X. Xue, W. Gao, T. Suzuki, Y. Ohishi, Toyota Technological Institute (Japan) 
$89821 \mathrm{X}$ Theoretical investigation of pulse dependent optical parametric amplification for microstructured optical fiber [8982-71]

E. P. Samuel, T. H. Tuan, K. Asano, T. Suzuki, Y. Ohishi, Toyota Technological Institute (Japan)

898212 Improving Shack-Hartmann wavefront sensor by using sub-wavelength annular apertures [8982-73]

H.-J. Chang, M.-H. Chung, C.-K. Lee, National Taiwan Univ. (Taiwan)

898220 Large dynamic range silicon photomultipliers for high energy physics experiments [8982-74]

Th. Ganka, Ch. Dietzinger, Univ. der Bundeswehr München (Germany); P. Iskra, F. Wiest, R. Fojt, KETEK GmbH (Germany); W. Hansch, Univ. der Bundeswehr München (Germany)

$898221 \quad$ Upconversion, size analysis, and fiber filling of $\mathrm{NaYF}_{4}: \mathrm{Ho}^{3+}, \mathrm{Yb}^{3+}$ crystals and nanocolloids [8982-75]

D. Patel, A. Lewis, D. Wright III, M. Velentine, D. Lewis, R. Valentine, Oakwood Univ. (United States); S. Sarkisov, SSS Optical Technologies, LLC (United States)

$898222 \quad$ Mitigating dispersive spectrometer size-performance limitations with HTVS optical components [8982-76]

J. T. Meade, B. B. Behr, Y. Bismilla, A. T. Cenko, B. DesRoches, A. Henkin, E. A. Munro, J. Slaa, S. Baker, D. Rempel, A. R. Hajian, Tornado Spectral Systems (Canada)

898223 Multimaterial rod-in-tube coextrusion for robust mid-infrared chalcogenide fibers [8982-77] G. Tao, S. Shabahang, CREOL, The College of Optics and Photonics, Univ. of Central Florida (United States); H. Ren, CREOL, The College of Optics and Photonics, Univ. of Central Florida (United States) and Jiangsu Normal Univ. (China); Z. Yang, The Australian National Univ. (Australia); X. Wang, CREOL, The College of Optics and Photonics, Univ. of Central Florida (United States) and Ningbo Univ. (China); A. F. Abouraddy, CREOL, The College of Optics and Photonics, Univ. of Central Florida (United States)

$898225 \quad$ Fiber Bragg grating filter using evaporated induced self assembly of silica nano particles [8982-79]

K. Hammarling, R. Zhang, A. Manuilskiy, H.-E. Nilsson, Mid Sweden Univ. (Sweden)

898227 Simulation-based design of a pixel for back-side-illuminated CMOS image sensor with thick photo-electric conversion element [8982-81]

T. Arai, H. Shimamoto, NHK Japan Broadcasting Corp. (Japan)

898228 Low loss coupling and splicing of standard single mode fibers with all-solid soft-glass microstructured fibers for supercontinuum generation [8982-82]

M. Murawski, Military Univ. of Technology (Poland) and InPhoTech Ltd. (Poland);

G. Stępniewski, Institute of Electronic Materials Technology (Poland) and Univ. of Warsaw (Poland); T. Tenderenda, M. Napierała, Z. Hołdyński, L. Szostkiewicz, Military Univ. of Technology (Poland) and InPhoTech Ltd. (Poland); M. Slowikowski, InPhoTech Ltd. (Poland); M. Szymanski, L. Ostrowski, Military Univ. of Technology (Poland) and InPhoTech Ltd. (Poland); L. R. Jaroszewicz, Military Univ. of Technology (Poland); R. Buczyński, Institute of Electronic Materials Technology (Poland) and Univ. of Warsaw (Poland); T. Nasiłowski, Military Univ. of Technology (Poland) and InPhoTech Ltd. (Poland) 
898229 The novel dual-waveband SWIR InGaAs FPAs with monolithic integration filter microstructure [8982-83]

H. Tang, X. Li, Shanghai Institute of Technical Physics (China); Y. Wang, Shanghai Institute of Technical Physics (China) and Univ. of Chinese Academy of Sciences (China); W. Duan, X. Shao, H. Gong, Shanghai Institute of Technical Physics (China)

Author Index 
Proc. of SPIE Vol. $8982898201-12$

Downloaded From: https://www.spiedigitallibrary.org/conference-proceedings-of-spie on 26 Apr 2023 Terms of Use: https://www.spiedigitallibrary.org/terms-of-use 


\section{Conference Committee}

Symposium Chairs

David L. Andrews, University of East Anglia Norwich (United Kingdom)

Alexei L. Glebov, OptiGrate Corporation (United States)

Symposium Cochairs

Jean Emmanuel Broquin, IMEP-LAHC (France)

Shibin Jiang, AdValue Photonics, Inc. (United States)

Program Track Chair

James G. Grote, Air Force Research Laboratory (United States)

Conference Chairs

Michel J. F. Digonnet, Stanford University (United States)

Shibin Jiang, AdValue Photonics, Inc. (United States)

Conference Program Committee

Jean-Luc Adam, Université de Rennes 1 (France)

Joel Bagwell, Edmund Optics Inc. (United States)

Rolindes Balda, Universidad del País Vasco (Spain)

Robert P. Dahlgren, Silicon Valley Photonics, Ltd. (United States) and University of California, Santa Cruz (United States)

Leonid Glebov, CREOL, The College of Optics and Photonics, University of Central Florida (United States)

Seppo K. Honkanen, University of Eastern Finland (Finland)

Jacques Lucas, Université de Rennes 1 (France)

Yasutake Ohishi, Toyota Technological Institute (Japan)

Aydogan Ozcan, University of California, Los Angeles (United States)

Giancarlo C. Righini, Museo Storica della Fisica e Center Studi e Ricerche Enrico Fermi (Italy)

Setsuhisa Tanabe, Kyoto University (Japan)

John M. Zavada, National Science Foundation (United States) 
Session Chairs

1 Lasers and Amplifiers

Shibin Jiang, AdValue Photonics, Inc. (United States)

2 Nanophotonics

Michel J. F. Digonnet, Stanford University (United States)

3 Fiber and Waveguide Fabrication

Seppo K. Honkanen, University of Eastern Finland (Finland)

4 Metamaterials and Plasmonics

Rolindes Balda, Universidad del País Vasco (Spain)

5 Microstructured Fibers and Components

Michel J. F. Digonnet, Stanford University (United States)

6 Yb-Doped Glasses and Fibers

Leonid B. Glebov, CREOL, The College of Optics and Photonics, University of Central Florida (United States)

7 Components and Detectors

Joel Bagwell, Edmund Optics Inc. (United States)

8 Optical and Electronic Properties of Materials

Yasutake Ohishi, Toyota Technological Institute (Japan)

9 Sensors

Jihong Geng, AdValue Photonics, Inc. (United States) 